\title{
Electricity Situation and Potential Development in Nigeria using Off-Grid Green Energy Solutions
}

\section{*AKHATOR, PE; OBANOR, AI; SADJERE, EG}

\author{
Department of Mechanical Engineering, University of Benin, Benin City, Nigeria. \\ *Corresponding Author Email: peter.akhator@uniben.edu
}

\begin{abstract}
Sustainable supply of electricity is crucial to comfortable living in homes and attaining economic development in any country. Despite being blessed with enormous green and non-green energy resources, Nigeria has been in a quandary about adequate generation and supply of electricity. The electricity crisis has, over the years, had significant adverse impact on the nation's socio-economic and technological development as well as standard of living of its citizens. This paper examines the problems in the electricity sector and the energy potential of green energy resources in Nigeria. The study reveals that the major source of electricity generation (natural gas) and mode of electricity transmission (a single national grid) in the country have been and are still being constrained by myriad of challenges, hence, the inability of the power sector to satisfy the electricity yearnings of Nigerians till date. The study also reveals that about $1182.375 \mathrm{GWh}$ of energy per day could be obtained from green energy resources in Nigeria and the provision of this quantity of energy through decentralized off-grid energy solutions would significantly increase electricity availability as well as accessibility in the country.
\end{abstract}

DOI: https://dx.doi.org/10.4314/jasem.v23i3.24

Copyright: Copyright (C) 2019 Akhator et al. This is an open access article distributed under the Creative Commons Attribution License (CCL), which permits unrestricted use, distribution, and reproduction in any medium, provided the original work is properly cited.

Dates: Received: 07 February 2019; Revised: 19 March 2019; Accepted 26 March 2019

Keywords: Electricity availability; Electricity crisis; Green electricity; Off-grid electricity

Access to affordable, clean and stable electricity supply is paramount to attaining and sustaining socioeconomic and technological development by any country. Conversely, dearth of electricity retards economic growth and impacts negatively on the citizens' quality of life. Nigerians, especially the rural dwellers, suffer some of the worst forms of electricity deprivation in the world (Eleri et al. 2012). Presently, approximately 95 million Nigerians, about $55 \%$ of the population, are without access to grid electricity, while those having access experience epileptic supply over $60 \%$ of the time (Aliyu et al. 2013; NPBR, 2015). Fossil fuels, which accounts for over $90 \%$ of Nigeria's foreign income earnings, have also been the major source of electricity generation in the country. The electricity generated is then evacuated via a national electricity grid. However, historically, electricity supply has never matched demand in the country due to high occurrences of significant technical and nontechnical constraints in the power supply value chain (NPBR, 2015). Hence, majority of Nigerian households and businesses are compelled to resort to privately owned petrol/diesel generators for much of their power needs for the better part of each day. Consequently, cost of production in the country has skyrocketed due to high cost of energy, many Nigerian spend huge percentage of their income on selfgeneration of electricity, and quality standard of living in the country is hindered. This has adversely affected the socio-economic growth and technological development in the country (Sambo et al. 2012). The finite nature of fossil fuel reserves, fluctuating price of crude oil in the international market, growing demand for carbon footprints reduction and the quest by several world economies to generate energy from green energy resources will impinge on the country's income earnings from fossil fuels in the nearest future. This would place the country' sustainability in great jeopardy unless other forms of energy sources are explored and developed for the purpose of income and electricity generation for the country. The overdependence of the power sector on fossil fuel and national electricity grid for electricity generation and evacuation has not yielded much result in terms of sustainable electrification of, and has stunted the development of green energy in, the country (Kennedy-Darling et al. 2008; Sambo, 2007). Hence, the need to diversify to achieve a broader electricity supply mix, which will ensure electricity security for Nigeria. The way forward is to explore green energy resources, such as hydro, biomass, solar and wind which are abundant in the country, and harness them for decentralized off-grid electricity generation. Deploying off-grid green energy solutions in Nigeria could potentially ameliorate the lingering electricity crisis in the country (Shaaban and Petinrin, 2014). Extensive research works have been conducted by various researchers (Udoakah and Umoh, 2014;

*Corresponding Author Email: peter.akhator@uniben.edu 
Ohunakin et al. 2014; Mohammed et al. 2014; Adaramola et al. 2011; Adaramola, 2014; Tunde, 2005; Uzoma et al. 2011; Sambo, 2009; Ojosu and Salawu, 1990; Ohunakin et al. 2011; Ohunakin, 2011; Ohimain, 2012; Mohammed et al. 2013; Ben-Iwo et al. 2016; Akinbami, 2001) on green energy development in Nigeria. Although these studies demonstrated the availability of green energy resources in all regions of Nigeria, there is presently no comprehensive review on green energy development for off-grid electricity generation in the country. This paper therefore aims to fill this gap by highlighting the benefits that could accrue to Nigeria if its vast green energy resources are harnessed for offgrid electricity generation. This review also considers the current electricity scenario and the energy potential of green energy resources in the country. However, the various technologies for off-grid green energy generation are not discussed as they are not the focus of this paper.

\section{MAATERIALS AND METHODS}

This study originated from the need to present decentralized off-grid energy generated from green energy resources as a viable approach to ameliorate the electricity crisis in Nigeria. The study involved several field visits to Ihovbor and Azura power plants located near Benin City, Edo State, Nigeria. A tour of the thermal power plants, which run on natural gas, was done and interviews were conducted about the challenges of electricity generation at the plants. Several study visits were also made to Benin Electricity Distribution Company (BEDC) located in Benin City to acquire information on electricity distribution and challenges to electricity distribution. A desk study was also done to retrieve available data on electricity generation and the challenges bedevilling the electricity sector in Nigeria. Availability and potential of green energy sources in the country, as well as the benefits of utilizing these resources for off-grid green electricity solutions in Nigeria were also examined and highlighted.

\section{RESULTS AND DISCUSSION}

Current Electricity Scenario in Nigeria: Nigeria's electrification rate of $45 \%$ is low, resulting in low per capita electricity consumption in the country over the years. Figure 1 presents electricity consumption per person in Nigeria between 1980 and 2014. Figure 1 shows the fluctuating amount of electricity available for consumption in Nigeria over these years. It can be observed from the graph that electricity consumption per capita attained a maximum value of $156.73 \mathrm{kWh}$ in 2012 and a minimum value of $50.87 \mathrm{kWh}$ in 1980 . In
2017 the per capita electricity consumption dropped to 129kWh (IndexMundi, 2017), placing the country far behind other developing nations in terms of grid electricity consumption. For example, in the same 2017, Ghana's per capita consumption (305kWh) was about 2.4 times higher than that of Nigeria, and South Africa's $(3,787 \mathrm{kWh})$ was approximately 29 times higher (IndexMundi, 2017). Figure 2 presents a comparison of Nigeria's per capita electricity consumption with some other African countries.

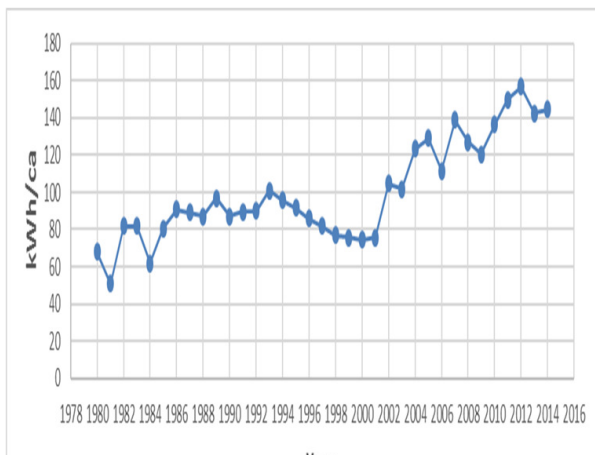

Years

Fig 1: Per capita electricity consumption in Nigeria from 1980 2014 (IEA, 2016)

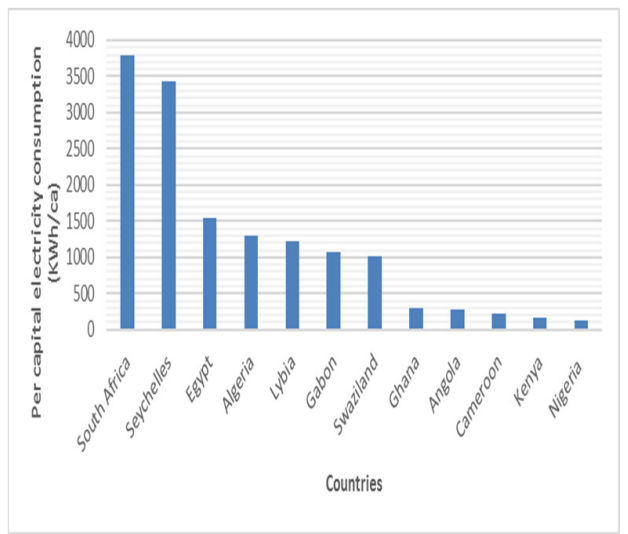

Fig 2: Per capital electricity consumption for a few African countries (Index Mundi, 2017)

Electricity generation in Nigeria: Over the last five decades, public electricity supply in Nigeria has been from a national electricity grid. During this period, the energy resources for electricity generation has been natural gas, oil, hydro and/or coal. At present, gas and hydro are the dominant energy resources utilized for electricity generation on the national electricity grid. The natural gas-fired power plants are mainly located in the south of the country while the hydroelectric power plants are located in the north. (NESISTATS, 
2018a). Between January 1 and August 31 2018, Nigeria's power plants generated an average peak electricity of 4434.585MW per day from 27 grid connected power plants (24 gas-fired and 3 large hydro), with total installed capacity of $14,243 \mathrm{MW}$ (NESISTATS, 2018a). Gas-fired power plants account for about $86 \%$ of the installed capacity while the three functional large hydropower plants provide the balance. Companies comprising former PHCN generation companies, Independent Power Plants
(IPPs) and National Integrated Power Projects (NIPPs) operate these power plants. Table 1 highlights the existing grid connected power plants in Nigeria. The peak and off-peak generation data in Table 1 were the breakdown for each power plant as at November 14, 2018 according to the Federal Ministry of Power, Works and Housing (FMPWH, 2018). Table 1 also shows that only about $31 \%$ and $24 \%$ of total installed capacity was generated during peak and off-peak period respectively

Table 1: Grid connected power plants in Nigeria (NESISTATS, 2018a; FMPWH, 2018)

\begin{tabular}{|c|c|c|c|c|c|}
\hline Power Plant & Turbine & Location & $\begin{array}{l}\text { Installed } \\
\text { capacity } \\
\text { (MW) }\end{array}$ & $\begin{array}{l}\text { Peak } \\
\text { Gen. } \\
\text { (MW) }\end{array}$ & $\begin{array}{l}\text { Off-peak } \\
\text { Gen. } \\
\text { (MW) }\end{array}$ \\
\hline A.E.S (IPP) & Gas & Lagos State & 270 & 0 & 0 \\
\hline Afam IV-V (NIPP) & Gas & Rivers State & 726 & 52 & 37 \\
\hline Afam VI (PPHCN) & Gas & Rivers State & 624 & 280 & 106 \\
\hline Alaoji (NIPP) & Gas/Steam & Abia State & 1074 & 0 & 0 \\
\hline ASCO (IPP) & Gas & River State & 294 & 0 & 0 \\
\hline Azura (IPP) & Gas & Edo State & 450 & 0 & 0 \\
\hline Egbin (PPHCN) & Steam & Lagos State & 1320 & 603 & 477 \\
\hline Gbarain (NIPP) & Gas & Bayelsa State & 225 & 110.6 & 0 \\
\hline Geregu I (PPHCN) & Gas & Kogi State & 414 & 141 & 86 \\
\hline Geregu II (NIPP) & Gas & Kogi State & 434 & 0 & 0 \\
\hline Ibom (IPP) & Gas & Akwa Ibom State & 190 & 80.2 & 87.2 \\
\hline Ihovbor (NIPP) & Gas & Edo State & 450 & 99.1 & 91.4 \\
\hline Odukpani (NIPP) & Gas & Cross River State & 561 & 0 & 0 \\
\hline Okpai (IPP) & Gas & Delta & 480 & 263 & 188 \\
\hline Olorunsogo (PPHCN) & Gas & Ogun State & 336 & 199.5 & 175.7 \\
\hline Olorunsogo II (NIPP) & Gas & Ogun State & 675 & 0 & 0 \\
\hline Omoku (PPHCN) & Gas & Rivers State & 150 & 43 & 41.7 \\
\hline Omotosho I (PPHCN) & Gas & Ondo State & 336 & 159 & 163.8 \\
\hline Omotosho II (NIPP) & Gas/Steam & Ondo state & 450 & 213.9 & 183.4 \\
\hline Paras Energy (IPP) & Gas & Ogun State & 96 & 69.4 & 68.6 \\
\hline Rivers (IPP) & Gas & Rivers State & 180 & 50 & 120 \\
\hline Sapele (PPHCN) & Steam & Delta State & 1020 & 92 & 45 \\
\hline Sapele II (NIPP) & Gas & Delta State & 450 & 176.6 & 119.5 \\
\hline Trans-Amadi (IPP) & Gas & Rivers State & 136 & 15.3 & 20.2 \\
\hline Delta (PPHCN) & Gas & Delta State & 972 & 515 & 291 \\
\hline Kainji (PPHCN) & Hydro & Niger State & 760 & 402 & 378 \\
\hline Jebba (PPHCN) & Hydro & Niger State & 570 & 456 & 431 \\
\hline Shiroro (PPHCN) & Hydro & Niger State & 600 & 443 & 259 \\
\hline Total & & & 14,243 & $4,463.6$ & $3,369.5$ \\
\hline
\end{tabular}

The total peak generation $(4,463.6 \mathrm{MW})$ on November 14, 2018 is in the same range as the daily average peak generation $(4434.585 \mathrm{MW})$ between January 1 and August 31 2018. This is an indication of little or no improvement in power generation in the country.

Challenges to Electricity Availability in Nigeria: Electricity crisis has lingered on for several decades now in Nigeria. Currently only about $31 \%$ of installed capacity is available for supply due to myriad of constraints in the power sector. The key constraints to generation and supply capacity include insufficient gas supply, aging and inadequate infrastructures, and liquidity issues. A major constraint to electricity generation and availability in the country is gas availability. About $86 \%$ of installed generation capacity is gas fired and hence relies on regular gas availability for optimal performance. Nigeria has one of the largest gas reserves in the world, however, the gas produced is mainly either exported, re-injected or flared (a total of 78\%) and only 9\% (0.8 Billion Standard Cubic Feet per Day) of total gas production is available to the thermal power stations (NPBR, 2015; Okere, 2015). Although, this quantity of gas is significantly low and grossly inadequate, not all gets 
to the power plants due to incessant vandalism of gas facilities, inadequate gas infrastructure, uneconomical gas prices, and ambiguous gas policies. Hence, most of the gas-fired thermal stations either shut down or reduce generation capacity thereby reducing total generation capacity (Bada, 2018; Thomas, 2018; Nnodim, 2017; Asu, 2017; Winsor, 2015; Obasi, 2016). According to the Federal Ministry of Power, Works and Housing, a total of $1705.5 \mathrm{MW}$ was unavailable on November 14, 2018 due to gas constraints (FMPWH, 2018). Industrial actions in Nigeria also contribute to gas unavailability. For example, the strike action embarked upon by NUPENG/PENGASSAN (unions in Nigerian oil and gas companies) in 2015, disrupted the supply of gas to the power stations and consequently caused a drop in electricity from national grid from postprivatization quantity of $3500 \mathrm{MW}$ to below $1000 \mathrm{MW}$ (Obanor, 2015). Furthermore, the aging and dilapidated transmission and distribution systems can hardly wheel out the generated electricity to consumers. The overloaded transmission network has several poor voltage profiles along the network and frequently experiences breakdowns and power losses. At an average of about $8.80 \%$ (January 2017 to May 2018), transmission losses across the network are high compared to emerging economy benchmark of approximately $2-6 \%$ (NERC, 2018). This reflects dire infrastructural challenges in the power sector. In 2018 alone, the national electricity grid collapsed eleven times (10 total and 1 partial) (FMPWH, 2018; Asu, 2018). This has been adduced to ineffective maintenance and poor management of these systems. Figure 3 displays the monthly energy losses due to transmission constraints between January 2017 and May 2018.

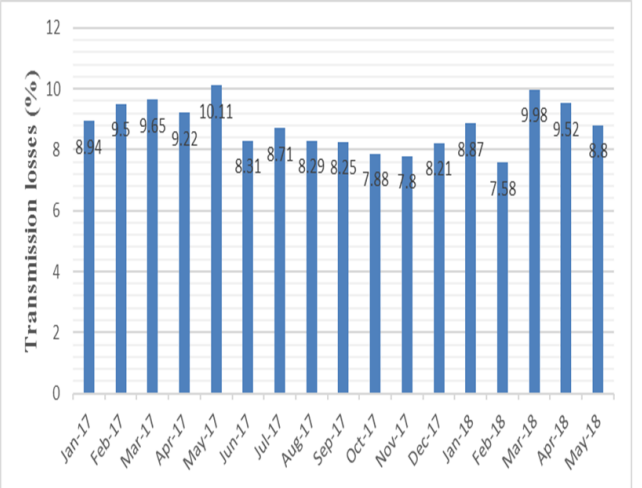

Fig 3: Monthly energy losses due to transmission constraints (NERC, 2018)

A recent stress test carried out on the distribution network indicates that the network cannot distribute more than $57 \%$ of the available electricity (Olawoyin, 2017). Hence, majority of the distribution companies
(DISCOS) reject power, which in turn causes high frequency problems in the transmission network. According to the Federal Ministry of Power, Works and Housing, a total of 640MW was unavailable on November 14, 2018 due to load rejection by the DISCOS (FMPWH, 2018). Internal generation plants challenges also constrain available electricity capacity. Some of these constraints are mainly maintenance and repairs, but most are the result of unexpected challenges such as trips, faults and leakages in plant components, burnt components and units requiring refurbishment. These internal operational constraints have led to shut down of at least three power plants in 2018 alone (Bada, 2018). Liquidity issues are other contributors to the current electricity crisis in Nigeria. Liquidity issues arising from non-cost reflective tariffs have been a major challenge for the successor companies since taking over the operations of the GENCOs and DISCOs in November 2013. The non-cost reflective power tariffs limit the companies' ability to meet their financial obligations, which include, among others, payment for gas purchased and servicing of loan facilities. The inability of the DISCOs to recover sufficient revenue from the consumers is another contributor to the liquidity issues in the power sector. The DISCOs are hardly able to recover commensurate funds from electricity consumers, (which are meant to sustain themselves and other power sector participants including GENCOs, gas suppliers and service providers), mainly due to power theft and poor power infrastructures (Ovuakporie and Ochayi, 2018). Consequently, the power sector participants are unable to get their money in full leading to a crunch in the power market and obviously stalling investment to increase generation capacity or to upgrade and expand the distribution networks (Ovuakporie and Ochayi, 2018).

Energy Potential of Green Energy Resources in Nigeria: Nigeria is blessed with abundant green energy resources such as biomass, hydro, solar and wind. These resources have an enormous potential for electricity generation, especially for decentralized offgrid utilization. This section highlights the availability and energy potential of these green energy resources. Hydro: Nigeria experiences high amount of rainfalls for a better part of the year especially in the southern and coastal regions. Hence, there exist several small and large rivers as well as streams across the country. Two major rivers, Benue and Niger, flow in southward from Republic of Cameroon and Niger Republic respectively. These rivers and streams have significant volumes and/depths of water that can be harnessed for small or large hydropower generation. The source of large hydropower generation in the country till date 
are Kainji, Jebba and Shiroro dams, all located in Niger State, with a combined installed capacity of 1930MW. However, large hydropower potential of about $10,966 \mathrm{MW}$ has been identified in various locations across the country (Mohammed et al., 2013). A feasibility study conducted in twelve states of the country identified over 277 small hydropower sites with a combined potential of $734.3 \mathrm{MW}$, waiting for investments (Zarma, 2006). However, there are small hydropower sites in almost all parts of Nigeria with an estimated capacity of 3,500MW (Sambo, 2009; Ohunakin et al, 2011), about $84 \mathrm{GWh}$ per day. Table 2 shows sixteen small hydropower stations with a total capacity of $67.7 \mathrm{MW}$ so far installed in Nigeria by both the government and private companies.

Biomass: Biomass is another green energy resource Nigeria has in abundance. The available biomass include agricultural residues, forest and lumbar processing residues, animal wastes, municipal wastes, and water hyacinths (Uzoma et al., 2011). These biomass, which are usually discarded indiscriminately in the country to the detriment of humans, animals and the environment, can be processed into briquettes, synthesis gas and biogas, which could be harnessed for off-grid energy generation.
Table 2: Operational small hydropower plants in Nigeria (Zarma,

\begin{tabular}{lll} 
& \multicolumn{2}{c}{ 20016) } \\
\hline River & State & Installed capacity (MW) \\
\hline Bagel I & Plateau & 1.00 \\
Bagel II & Plateau & 2.00 \\
Ouree & Plateau & 2.00 \\
Kurra & Plateau & 8.00 \\
Lere I & Plateau & 4.00 \\
Lere II & Plateau & 4.00 \\
Bakalori & Sokoto & 3.00 \\
Tiga & Kano & 6.00 \\
Oyan & Ogun & 9.00 \\
Ikere Gorge & Oyo & 6.00 \\
Omi-Kampe & Kogi & 2.00 \\
Doma & Nasarawa & 1.00 \\
Zobe & Katsina & 0.30 \\
Jibiya & Katsina & 4.00 \\
Donga & Taraba & 0.40 \\
Waya & Bauchi & 015 \\
Total & & $\mathbf{6 7 . 7}$ \\
\hline
\end{tabular}

It is worthy of note that utilizing these biomass for electricity generation poses no threat to food security and forest preservation in the case of Nigeria as they are considered as useless materials to be discarded. Table 3 shows estimated biomass resources in Nigeria.

Table 3: Biomass resources in Nigeria (Adapted from Ben-Iwo et al., 2016; Akhator et al., 2016a; Ohimain, 2012)

\begin{tabular}{ll}
\hline Biomass & Quantity per day (tonnes) \\
\hline Agro-residues & $109,401.10$ \\
Forest \& wood processing residues & $14,246.58$ \\
Animal residues & 227,500 \\
Organic fraction municipal solid waste (food waste) & $34,442.80$ \\
Combustible municipal solid waste & $16,790.22$ \\
\hline
\end{tabular}

$1 \mathrm{~kg}$ of fresh animal waste produces about $0.03 \mathrm{~m}^{3}$ of biogas (Ben-Iwo et al, 2016), hence, Nigeria can produce about 6.8 million $\mathrm{m}^{3}$ of biogas daily from fresh animal wastes. Total amount of biogas obtainable from food wastes can be estimated using equation (1) (Kigozi et al, 2014).

$$
\mathrm{TBO}=\mathrm{AFW} \times \mathrm{VS}(\%) \times \mathrm{BY}
$$

Where, TBO $=$ total biogas obtainable $\left(\mathrm{m}^{3}\right)$, AFW $=$ amount of food waste (tonnes), BY = biogas yield $\left(\mathrm{m}^{3} / \mathrm{t} \mathrm{VS}\right)$. VS (volatile solids) is $94.90 \%$ of TS (total solids) and TS is $27.14 \%$ of food waste quantity, biogas yield from food waste is about $367 \mathrm{~m}^{3} / \mathrm{t} \mathrm{VS}$ (Kigozi et al, 2014).

Applying these values in equation (1), about 3.3 million $\mathrm{m}^{3}$ of biogas per day is obtainable from food waste in Nigeria. This gives about 10.1 million $\mathrm{m}^{3}$ of obtainable biogas from both animal and food wastes generated per day. $1 \mathrm{~m}^{3}$ of biogas can be converted to about $1.7 \mathrm{~kW}$ of electricity (Eriksson, 2010); therefore, the $10.1 \mathrm{~m}^{3}$ of biogas would generate about 17,170MW of electricity. According to Akhator et al, $2016 \mathrm{~b}$, combusting $3.6 \mathrm{ton} / \mathrm{h}$ of solid waste in a steam power facility can generate $1.4 \mathrm{MW}$ of electricity.

\begin{tabular}{ll} 
Table 4: Power potential of biomass resources in Nigeria \\
\cline { 2 - 2 } Biomass & Power potential (MW) \\
\hline Agro-residues & $14,889.65$ \\
$\begin{array}{l}\text { Wood residues } \\
\text { Animal }\end{array}$ & 562.215 \\
residues and & 17,170 \\
food waste & \\
$\begin{array}{l}\text { Combustible } \\
\text { municipal } \\
\text { solid waste }\end{array}$ & $6,529.53$ \\
Total & $\mathbf{3 9 , 1 5 1 . 3 9 5}$
\end{tabular}

Hence, 16,790.22 tonnes of combustible solid waste would generate about $6,529.53 \mathrm{MW}$ of electricity. According to Simonyan and Fasina (2013), about $14,889.65 \mathrm{MW}$ and $562.215 \mathrm{MW}$ can be obtained from agro-residues and wood residues respectively. This gives a total of about 39,151.395MW of electricity, which translates to about $939.634 \mathrm{GWh}$ of energy per 
day from biomass in Nigeria. Table 4 presents the power potential of biomass resources in Nigeria.

Solar: The intensity and duration of solar irradiation increases from south to north of the country. Previous studies have shown that the average solar irradiation increases from about $3.5 \mathrm{kWh} / \mathrm{m}^{2}$ per day in the coastal south to about $7.0 \mathrm{kWh} / \mathrm{m}^{2}$ per day in the arid extreme North (Oyedepo, 2012; Fadere, 2009; Odukwe and Enibe, 1988). Hence, assuming an average solar irradiation of $5.25 \mathrm{kWh} / \mathrm{m}^{2}$ per day, Nigeria therefore receives a total solar energy of about $4781.55 \mathrm{GWh}$ per day on its $910,771 \mathrm{~km}^{2}$ land area. Hence, deploying the right technology, solar irradiation in almost every location in Nigeria is viable for electricity generation.

Solar photovoltaic (PV) are devices used to capture sunlight and convert them directly to electricity. The efficiency of this technology is enhanced by the intensity of sunlight and Nigeria being a tropical country has high intensity sunlight for better part of the day, making this technology a viable one for offgrid energy solutions in Nigeria. To estimate the

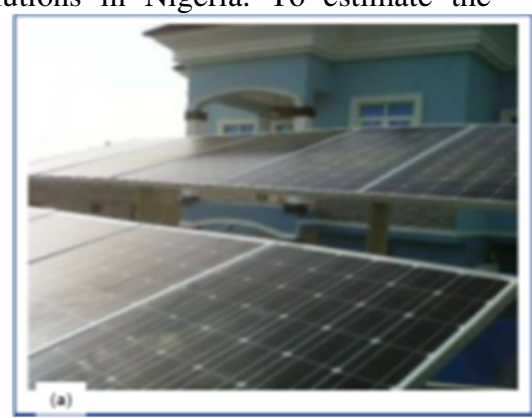

obtainable energy output in Nigeria from a PV system, equation (2) (Suri et al, 2007) is used.

$\mathrm{E}=\mathrm{Ar} \mathrm{B} \mathrm{P}_{\mathrm{R}}$

Where, $\mathrm{E}=$ estimated energy $(\mathrm{kWh}), \mathrm{A}=$ total solar panel area $\left(\mathrm{m}^{2}\right), \mathrm{r}=$ solar panel efficiency $(\%), \quad \mathrm{B}=$ daily average solar irradiation on horizontal/inclined panels, and $\mathrm{P}_{\mathrm{R}}$ is system performance ratio, (typical value is 0.75 ).

Nigeria has a land area of $910,771 \mathrm{~km}^{2}$, of which $96,043 \mathrm{~km}^{2}$ is occupied by forest (Olaniyan, 2018). This leaves available land area of $814,728 \mathrm{~km}^{2}$. Assuming $25 \%$ of this available land area is utilized for solar energy harvesting using PV systems, solar panels efficiency of $15 \%$, system performance ratio of 0.75 and an average solar irradiation of $5.25 \mathrm{kWh} / \mathrm{m}^{2}$ per day, the total daily estimated energy output in Nigeria will be $120.3 \mathrm{GWh}$.

Some solar projects in Nigeria are shown in Figures 4 and 5 .

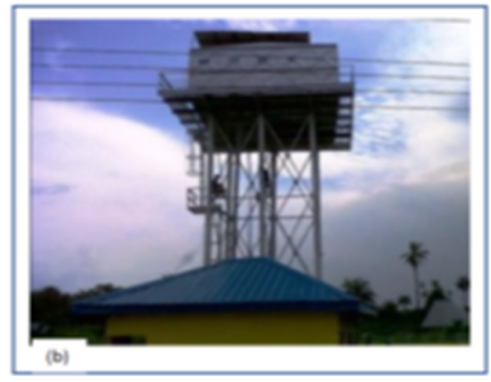

Fig 4: (a) Solar powered home in Lekki-Ajah, Lagos State, (b) Solar powered water borehole in Port Harcourt, Rivers State (Ojike, 2015)
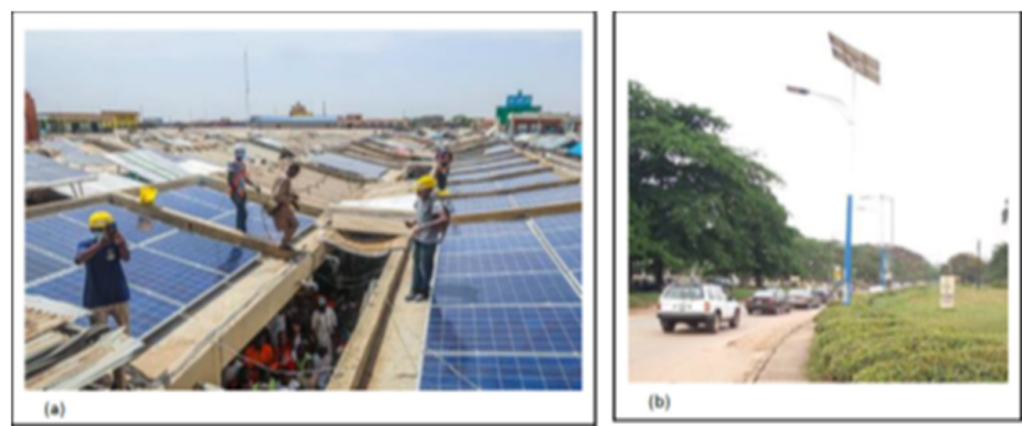

Fig 5: (a) Solar IPP at Sura Shopping Complex, Lagos State (REA, 2018), (b) Solar powered streetlights in University of Benin, Edo State (image by authors)

Wind: Nigeria generally experiences higher winds in the north than in the south of the country. The wind resource mapping conducted by the Ministry of Science and Technology indicated that wind speeds of up to $9 \mathrm{~m} / \mathrm{s}(32.4 \mathrm{~km} / \mathrm{hr})$ were recorded in the northern cities of Jos and Kano. The report of the survey, presented in Table 5, also reveals other promising locations with significant wind speeds sufficient for electricity generation in wind farms using wind energy technologies (Ojosu and Salawu, 1990; Akinbami, 2001; Ohunakin, 2011). Wind energy technology involves the conversion of the kinetic energy of moving air into electricity with the aid of wind turbines. Horizontal Axis Wind Turbine (HAWT) and Vertical Axis Wind Turbine (VAWT) are the two basic types of wind turbines for such conversion (EIA, 2017). However, due to its higher efficiency, HAWT will be preferable for usage in Nigeria. Potential wind power obtainable at a particular site can be estimated using equation (3) (Sarkar and Behera, 2012).

$$
\mathrm{W}_{\mathrm{p}}=0.5 \times \rho \times \mathrm{A} \times \mathrm{V}^{3} \times \mathrm{C}_{\mathrm{p}}
$$

Where, $\mathrm{W}_{\mathrm{p}}=$ wind power (watts), $\rho=$ air density $\left(\mathrm{kg} / \mathrm{m}^{3}\right), \mathrm{A}=$ swept area $\left(\pi \mathrm{D}^{2}\right)$ of the wind turbine rotor 
$\left(\mathrm{m}^{2}\right), \mathrm{D}=$ rotor blade diameter $(\mathrm{m}), \mathrm{V}=$ wind speed $(\mathrm{m} / \mathrm{s}), \mathrm{C}_{\mathrm{p}}$ is coefficient of performance. Assuming $\rho=$ $1.23 \mathrm{~kg} / \mathrm{m}^{3}, \mathrm{C}_{\mathrm{p}}=0.59$ (Bertz limit), $\mathrm{D}=27 \mathrm{~m}$ (onshore), the wind power potential for different locations across Nigeria is given in Table 5.

\begin{tabular}{|c|c|c|}
\hline City & $\begin{array}{l}\text { Daily average wind speed }(\mathrm{m} / \mathrm{s}) \\
\text { at } 10 \mathrm{~m} \text { height (Adapted from } \\
\text { Ohunakin, 2011) }\end{array}$ & $\begin{array}{l}\text { Estimated } \\
\text { wind power } \\
\text { (MW) }\end{array}$ \\
\hline Shaki & 4.50 & 37.86765 \\
\hline Iseyin & 4.01 & 26.79563 \\
\hline Lagos mainland & 4.61 & 40.71305 \\
\hline Lagos island & 4.69 & 42.86959 \\
\hline Calabar & 4.60 & 40.44868 \\
\hline Enugu & 5.73 & 78.17983 \\
\hline Sokoto & 7.21 & 155.7531 \\
\hline Gusau & 6.17 & 97.60821 \\
\hline Kaduna & 5.13 & 56.10259 \\
\hline Katsina & 7.45 & 171.8303 \\
\hline Zaria & 6.08 & 93.39886 \\
\hline Kano & 9.39 & 344.0548 \\
\hline Ilorin & 5.04 & 53.20133 \\
\hline Mina & 5.36 & 63.99193 \\
\hline Bauchi & 4.83 & 46.8244 \\
\hline Potiskum & 5.25 & 60.13243 \\
\hline Maiduguri & 5.22 & 59.10747 \\
\hline Jos & 9.47 & 352.9237 \\
\hline Yola & 4.16 & 29.9165 \\
\hline Total & & 1851.72 \\
\hline
\end{tabular}

Table 5 shows that a total of $1,851.72 \mathrm{MW}$ of wind power can be generated in Nigeria, which translate to about $44.441 \mathrm{GWh}$ per day, with major contributions from Jos, Kano, Katsina and Sokoto, which are cities located in the Northern part of the country. Although, it is believed that there could be significant wind energy potential in offshore locations around Nigeria, its estimation was excluded from this review due to lack of data on offshore wind speed in Nigeria. At present, a 10MW wind farm is under construction in Katsina State (Sunday and Shimnon, 2018). Table 6 highlights the daily energy potential from green energy resources in Nigeria It can be observed from Table 6 that about $1182.375 \mathrm{GWh}$ of energy per day can be obtained from green energy resources in Nigeria. This quantity of power is about 12 times the amount of energy currently generated daily in the country. The quantity of power translates to daily electricity consumption of about $2,172 \mathrm{kWh} /$ person in Nigeria. However, with the constraints currently bedevilling the national grid; it would be more beneficial to supply this enormous power to Nigerians through decentralized off-grid solutions. Figure 6 shows the daily energy potential of Nigeria's green energy resources as given in table 6 .

Benefits of Off-Grid Green Electricity Generation in Nigeria: Off-grid green electricity can be described as electricity generated from green energy resources in stand-alone electricity facilities that are not connected to a national grid (IRENA, 2015). These stand-alone facilities, usually small to medium scale, can supply cost-effective electricity via mini-grids or directly to small settlements and business clusters with poor supply from the national grid or not connected to the national grid. Off-grid green energy solutions are enjoying increasing steady deployment across the globe, especially in developing countries because of their numerous benefits, which include cheap, reliable and stable supply of electricity, localized usage, no transmission losses, and minimum space requirement, (IRENA, 2015).

Table 6: Daily energy potential of green energy resources in

\begin{tabular}{ll}
\multicolumn{2}{c}{ Nigeria } \\
\hline Green Resources & Energy potential (GWh) \\
\hline Biomass & 933.634 \\
Solar & 120.300 \\
Hydro & 84.000 \\
Wind & 44.441 \\
Total & $\mathbf{1 1 8 2 . 3 7 5}$ \\
\hline
\end{tabular}

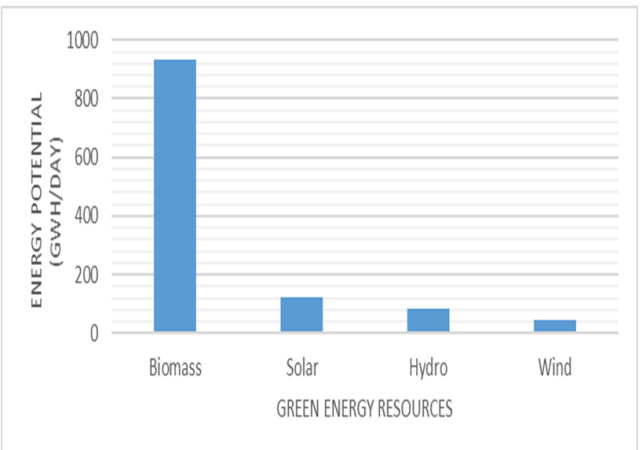

Fig 6: Daily energy potential of green energy resources in Nigeria

The present electricity quagmire in Nigeria has obviously shown that depending mainly on natural gas is inadequate to satisfy the country's electricity demands. Considering the abundant green energy resources in the country, Nigerian government need to make significant investments in off-grid electricity generation using these resources and thereby chart a new and better electricity future for the country. Offgrid green electricity solutions are very well suited for business clusters as well as rural and peri-urban settlements, and could be a cheap and clean option for 
increasing electricity access to citizens as evidenced in other several developing countries (Urmee et al., 2009; Hiremath et al., 2009; Haanyika, 2008). Like other developing countries, Nigeria has a lot to benefit if its vast green energy resources are harnessed for off-grid green electricity generation. Some major benefits for the country are delineated in this section.

Improved Rural Electrification: At present, only $26 \%$ of rural households in Nigeria are connected to grid electricity, which is unavailable and unstable most of the time (RESIP, 2016). The topography and remoteness of these rural areas have made it complicated to connect them to the national grid. With the generation and distribution arms of the Nigerian power sector now privatized, it is obvious that for logistics and economic reasons, extending the national electricity grid to rural areas will not be attractive to private investors. Such areas may remain unelectrified for the distant future except an alternative source of energy that is not grid dependent is explored. Off-grid green energy solutions have proven to be a viable and an efficient solution for decentralized rural electrification. Such rural electrification programmes have increased electricity access in rural areas and improve substantially the quality of life of rural dwellers in other climes (IRENA, 2015; Dasappa et al., 2011; Nouni et al., 2007; Sambo, 2005).

Increased Electricity Availability to Industrial and Residential Premises: Constant electricity supply is essential to the growth and sustainability of industries as well as comfort in homes. Having access to regular and stable electricity has been a major headache for industries in the country and this is having a huge toll on their operations and sustenance. Off-grid green electricity generation could provide sustainable electricity independence for these industries, and hence, enable them perform optimally, make more profits and even create jobs. Towards this end, the Federal Government of Nigeria through the Rural Electrification Agency rolled out Energizing Economies Initiatives (EEI). The EEI is aimed at providing sustainable and clean electricity to small and medium scale businesses within economic clusters across the country using mainly off-grid green solutions. Beneficiaries of the initiatives include Sabon Gari market (Kano State) and Sura shopping complex (Lagos State) where over 12,000 and 1047 shops are respectively being powered by solar photovoltaics. The joint survey conducted by the Rural Electrification Agency (REA), World Bank (WB) and the Rocky Mountain Institute (RMI) revealed that offgrid solutions could save about 1.5 trillion naira annually for Nigerian homes and businesses (Sajou, 2018).

Job and Income Creation: Off-grid green electricity generation systems would require personnel during the construction as well as operations and maintenance afterwards. These personnel could be sourced largely locally, thereby creating jobs for Nigerians. Majority of rural dwellers in Nigeria are farmers, due to poor crops storage and long distances to the markets, these farmers suffer high post-harvest losses. With the availability of off-grid green solutions, these spoilt crops can be harnessed in off-grid green electricity systems to generate energy. This would increase the profits the farmers could make from their farms, thereby raising their income levels. Those in the lumber industries would also experience increase in their profits as the residues from their wood processing activities will be utilized for off-grid electricity generation. Jobs and income could also be created for collectors of these residues, as off-grid green energy facilities are capable of providing local markets for biomass feedstock. Such job and income creation could enhance rural economies and reduce rural to urban migration in the country, which is predominantly occasioned by search for jobs that are seldom available in rural areas.

Improved Community and Environmental Sanitation: Globally, there are increasing concerns about fossilfuel based electricity generation. This is because such electricity generation emits greenhouse gases, which have led to global warming and its attendant adverse consequences. Despite the differences in regional economies, the adverse effects of global warming are experienced by all, hence, the need for concerted efforts to reduce fossil-fuel based electricity generation and the resulting emissions. Off-grid green electricity solutions are sure ways to reduce such emissions for sustainable and safe environment. Besides benefits on the energy front, Nigeria stands to gain improved community sanitation, as biomass (which are currently causing environmental nuisances in the country due to poor management methods) will be converted to bio-electricity for off-grid utilization. Noise pollutions from the use of several generating sets in homes and business clusters will be eliminated. The emissions from the use of these generators will also be eliminated thereby providing a cleaner, safe residential, and business environments.

Considerable Immunity from Liquidity Crisis: There is a huge market for power in Nigeria, however, the substantial power losses along the generation transmission - distribution networks, which culminate in financial losses as the final quantity of power available for sale to consumers are less than the generated quantity. Off-grid green solutions could address these problems, as the generated electricity is free from transmission losses and directly available to the consumers who will be ready and happy to pay for regular and stable electricity provided and consumed. This will help to immune investors from the current liquidity crisis within the power sector. The joint survey by the REA, WB and RMI also submitted that developing off-grid solutions in Nigeria could create a huge market to the tune of 3.2 trillion naira annually (Sajou, 2018). 
Conclusion: This review shows that an estimated energy potential of about $934 \mathrm{GWh}, 84 \mathrm{GWh}, 44 \mathrm{GWh}$ and $120 \mathrm{GWh}$ can be obtained daily from biomass, hydro, wind and solar respectively. It also indicates that, like in other developing countries, Nigeria stands to benefit immensely if this energy is provided to consumers using off-grid electricity solutions. Hence, the urgent need for the government to be more pragmatic in diversifying Nigeria's electricity supply mix by encouraging, through clear and action backed policies, investments in off-grid green electricity solutions.

\section{REFERENCES}

Adaramola, MS (2014). Viability of grid-connected solar PV energy system in Jos, Nigeria. Int J

Electrical Power Energy Syst. 61: 64-9

Akhator, EP; Igbinomwanhia, DI; Obanor, AI (2016a). Potential for commercial biogas production of biogas from domestic food waste generated in Benin metropolis, Nigeria. J. Appl. Sci. Environ. Manage. 20(2): $369-373$.

Akhator, EP; Obanor, AI; Igbinomwanhia, DI (2016b). Thermal analysis of a small scale solid wastefired steam boiler for power generation in Benin city, Nigeria. Nigerian Journal of Technology. 35(3): 555561.

Akinbami, JFK (2001). Renewable energy resources and technologies in Nigeria - present situation, future prospects and policy framework, Mitigation and Adaptation Strategies for Global Change. 6, 155181

Aliyu, A; Ramli, A; Saleh, M (2013). Nigeria electricity crisis: power generation capacity expansion and environmental ramifications. Energy, 61, 354-367.

Asu, F (2017). 13 power plants lose $3,124 \mathrm{MW}$ to gas shortage. Punch, https://punchng.com/13-powerplants-lose-3124mw-gas-shortage/

(Accessed $15 / 2 / 2018$ )

Asu, F (2018). Blackout as power grid collapses again. Punch, http://punchng.com/breaking-total-blackouthits-nigeria-as-power-grid-collapses/ (Accessed 20/6/2018).

Bada, G (2018). 8 power plants shut down as Nigeria loses N108 billion in first quarter over operational constraints. https://www.pulse.ng/bi/strategy/powerplants-shutdown-as-nigeria-loses-n108b-overconstraints-id8241546.html\# (Accessed on 26/11/2018).

Ben-Iwo, J; Manovic, V; Longhurst, P (2016). Biomass resources and biofuels potential for the production of transportation fuels in Nigeria. Renewable and Sustainable Energy Reviews, 63: 172-192.

Ovuakporie, E; Ochayi, C (2018). Discos are technically insolvent-BPE. https://www.vanguardngr.com/2018/07/discos-aretechnically-insolvent-bpe/ (Accessed 2/8/2018).
.Discos cannot accommodate Gencos 8,000MW generation capacity (2017). http://energymixreport.com/discoscannot-accomodate-gencos-8000mw-generationcapacity-apgc/ (Accessed 4/6/2018).

EIA (2017). Wind explained: types of wind turbines. https://www.eia.gov/energyexplained/index.php?page =wind types of turbines (Accessed on 27/11/2018).

Eleri, E.O., Ugwu, O., and Onuvae, P. (2012). Expanding access to pro-poor energy services in Nigeria. International Centre for Energy, Environment \& Development. Retrieved from http://www.iceednigeria.org (Accessed on February 10, 2016).

Eriksson, O (2010). Environmental technology assessment of natural gas compared to biogas. https://www.intechopen.com/books/naturalgas/environmental-technology-assessment-of-naturalgas-compared-to-biogas (Accessed on 1/1/2019)

Fadare, DA (2009). Modelling of solar energy potential in Nigeria using artificial neural network model. Applied Energy, 86, 1410-1422.

Federal Ministry of Power, Works and Housing (FMPWH) (2018). Daily operational report. http://www.pwh.gov.ng/management/uploads_images/ 15422463228375.pdf (Accessed on 14/11/2018).

Haanyika, CM (2008). Rural electrification in Zambia: a policy and institutional analysis. Energy Policy, $36,1044-58$

Hiremath, RB; Kumar, B; Balachandra, PN; Ravindranath, H; Raghunandan, BN (2009). Decentralised renewable energy: scope, relevance and applications in the Indian context. Energy for Sustainable Development. 13, 410.

IEA (2016). Nigeria- Electric power consumption ( $\mathrm{kWh}$ per capita).

https://www.iea.org/statistics/?country=NIGERIA\&year=2 $016 \&$ category $=\mathrm{Key} \% 20$ indicators \&indicator $=\mathrm{ElecCO}$ nsPerCapita\&mode $=$ chart \&categoryBrowse $=$ false $\&$ da taTable=ELECTRICITYANDHEAT\&showDataTable =false (Accessed on 19/11/2018).

IndexMundi (2017). Energy: electricity consumption per capita.

https://www.indexmundi.com/map/?t=0\&v=81000\&r $=\mathrm{af} \& \mathrm{l}=\mathrm{en}$ (Accessed on 19/11/2018).

International Renewable Energy Agency (IRENA) 2015. Off-grid renewable energy systems: status and methodological issues. https://www.irena.org/DocumentDownloads/Publicati ons/IRENA_Off-

grid_Renewable_Systems_WP_2015.pdf/ (Accessed 12/3/2018.

Kennedy-Darling, J; Hoyt, N; Murao, K; Ross, A (2008). The Energy Crisis of Nigeria: An Overview and Implications for the Future. Chicago: The University of Chicago. 
Kigozi, R., Aboyade, A.O. and Muzenda, E. (2014). Sizing of an anaerobic digester for the organic fraction of municipal solid waste. World Congress on Engineering and Computer Science, San Francisco, USA, 2: 22-24

Mohammed, YS; Mustafa MW; Bashir N; Ogundola MA; Umar U (2014). Sustainable potential of bioenergy resources for distributed power generation development in Nigeria. Renewable and Sustainable Energy Reviews, 34:361-70.

Mohammed, YS; Mustafa, MW; Bashir, N; Mokhtar, AS (2013). Renewable energy resources for distributed power generation in Nigeria: A review of the potential. Renewable and Sustainable Energy Reviews, 22: 257268.

NERC (2018). Transmission losses. http://www.nercng.org/index.php/library/industrystatistics/transmission/471-transmission-loss\#data (Accessed on 15/11/2018)

NESISTATS (2018a). Power sector operators: generation companies. http://mypower.ng/investors/power-sectorplayers-2/\#1505841439620-94752ada-aa0312e5-0646 (Accessed 17/11/2018)

NESISTATS (2018b). Electricity supply statistics. http://mypower.ng/investors/statistics $2 /$ Accessed 4 September 2018).

NPBR, (2015). Nigeria Power Baseline Report developed by the Advisory Power Team, Office of the Vice President, Federal Government of Nigeria in conjunction with Power Africa. https://mypower.ng/wpcontent/uploads/2018/01/Baseline-Report.pdf (Accessed on 16/10/2018).

Odukwe, AO; Enibe, SO (1988). Energy resources of Nigeria. Solar and Wind Technology, 5:335-338.

Ohimain, EI (2012). The prospects and challenges of waste wood biomass conversion to bioelectricity in Nigeria. Journal of Waste Conversion, Bio-Products and Biotechnology 1: 3-8

Ohunakin OS; Adaramola MS; Oyewola OM; Fagbenle RO (2014). Solar energy applications and development in Nigeria: drivers and barriers. Renewable and Sustainable Energy Reviews, 32:294-301.

Ohunakin, OS (2011). Wind characteristics and wind energy potential assessment in Uyo, Nigeria. Journal of Engineering and Applied Science., 6: 141-146

Ohunakin, SO; Ojolo, SJ; Ajayi, OO (2011). Small hydropower (SHP) development in Nigeria: An assessment. Renewable and Sustainable Energy Reviews, 15: 2006-2013

Ojike, C (2015a). 7KVA solar power home installation in Lekki-Ajah by PSC Solar UK. https://pscsolaruk.com/blog/project/7kva-solar-powerhome-installation-in-lekki-ajah-by-psc-solar-uk/ (Accessed 11/11/2018.

Ojike, C (2015b). Port Harcourt Solar Powered Water Borehole https://pscsolaruk.com/blog/project/port-harcourtsolar-powered-water-borehole-installation-by-pscsolar/(Accessed 11/11/2018.

Ojosu, JO; Salawu, A (1990). A survey of wind energy potentials in Nigeria. Solar and Wind Technology, 7: 155-167.

Okere, R. (2015). Nigeria's untapped gas reserves and declining crude oil fortunes. Guardian, https://guardian.ng/energy/nigerias-untapped-gasreserves-and-declining-crude-oil-fortunes/(Accessed 25/3/2018)

Olaniyan, A (2018). How poor management of Nigerian forest led to exploitation by criminals. The Conversation. https://theconversation.com/how-poormanagement-of-nigerian-forests-led-to-exploitationby-criminals-108434/ (Accessed 18/1/2019).

Olawoyin, O (2017). Shocking: Why Nigerians can't receive more than $4,600 \mathrm{MW}$ of electricity no matter volume generated. Premium Times, www.premiumtimesng.com/news/headlines/229203shocking-nigerians-can't-receive-4600mw-electricityno-matter-volume-generated-official.html/(Accessed 25/4/2018).

Oyedepo, SO (2012). On energy for sustainable development in Nigeria. Renewable and Sustainable Energy Reviews, 16: 2583-2598.

Power sector loss rose by $13 \%$ in first week of July http://energymixreport.com/power-sector-loss-roseby-13-in-first-week-of-july/ (Accessed 12/8/2018).

REA, (2018). https://web.facebook.com/REANigeria/photos/a.1593 374624090149/2003065673121040/?type $=3 \&$ theater

RESIP, (2016). Rural Electrification Strategy and Implementation Plan prepared by the Federal Ministry of Power and Housing, Nigeria. http://www.power.gov.ng/Press\%20Release/RURAL \%20ELECTRIFICATION\%20STRATEGIC\%20IMP LEMENTAION\%20PLAN\%20(RESIP).pdf (Accessed 15/3/2018).

Sambo, A (2007). Alternative generation and renewable energy. $2^{\text {nd }}$ Power Business Leader Summit, Ibom Gulf Resort, Akwa Ibom State, Nigeria, 12 ${ }^{\text {th }}-14^{\text {th }}$ December.

Sambo, AS; Garba, B; Zarma, IH; Gaji, MM (2012). Electricity generation and the present challenges in the Nigerian power sector. Journal of Power and Energy Engineering. 6:1050-9.

Sambo, AS (2009). Strategic developments in renewable energy in Nigeria. International Association for Energy Economics, 16.

Sarkar, A; Behera, DK (2012). Wind turbine blade efficiency and power calculation with electrical analogy. International Journal of Scientific and Research Publications, 2(2): 1-5

Shaaban, M; Petinrin, JO (2014). Renewable energy potentials in Nigeria: meeting rural energy needs. Renewable and Sustainable Energy Reviews, 29:72-84. 
Simonyan, K; Fasina, O (2013). Biomass resources and bioenergy potentials in Nigeria. African Journal of Agricultural Research, 8 (40): 4975 - 4989.

SolarGIS (2018). Solar resources maps of Nigeria. https://solargis.com/maps-and-gisdata/download/nigeria/ (Accessed on 20/11/2018).

Sunday, SE; Shimnon, PE (2018). Grid to get 10MW from Katsina wind farm 8 years after. Daily Trust, https://www.dailytrust.com.ng/grid-to-get-10mwfrom-katsina-wind-farm-8-years-after.html (Accessed on $13 / 11 / 2018)$.

Suri, M; Huld, TA; Dunlop, ED; Ossenbrink, HA (2007). Potential of solar electricity generation in the European Union member states and candidate countries. Solar Energy, 81: 1295-1305.

Thomas, D (2018) Flared gas enough to generate $3 \mathrm{GW}$ of electricity http://energymixreport.com/flared-gasenough-to-generate-3gw-of-electricity-dada-thomas/

(Accessed 12/8/2018).

Tunde, AO (2005). Small hydro schemes - taking Nigeria's energy generation to the next level. In: Proceedings of the IEEE Power Engineering Society Inaugural Conference and Exposition in Africa, p. 112-9.
Udoakah, YON; Umoh, MD (2014). Sustainably meeting the energy needs of Nigeria: The renewable options. In: Proceedings of the IEEE International Energy Conference (ENERGYCON). pp. 326-332.

Urmee, T; Harries, D; Schlapfer, A (2009). Issues related to rural electrification using renewable energy in developing countries of Asia and Pacific. Renewable Energy, 34: 354-357.

Uzoma, CC; Nnaji, CE; Ibeto, CN; Okpara, CG; Nwoke, OO et al. (2011). Renewable energy penetration in Nigeria: a study of the South-East Zone, Journal of Environmental Science and Technology, 5: 1-5.

Winsor, M (2015). Nigeria's power supply drops from pipeline vandalism, rising temperatures and a fragile infrastructure. International Business Times, https://www.ibtimes.com/nigerias-power-supplydrops-pipeline-vandalism-rising-temperatures-fragile1904622/(Accessed 15/2/2018)

Zarma, IH (2006). Hydropower resources. A paper presented at the $2^{\text {nd }}$ Hydropower for Today Conference, Hangzhou, China, June 19-23. 